\title{
Rolul implicării parentale în procesul de intervenție logopedică
}

\section{Lucia BOTEZAT ${ }^{1}$}

\begin{abstract}
This research aims to extend and adapt the therapy techniques, specific to the speak and language disorders domain, for their use in the child's family environment. The main subjects of the research are the parents of the children diagnosed with speaking problems.

By encouraging the parent's active participation within the logopedic therapy, it is intended to teach them, so that they could continue the therapy in the child's every day life.

Moreover, the therapeutic collaboration between the speech therapist, the child and the parents allow to valorise the observations made by the parents related to the child environment and every day life, completing the information obtained by the therapist during the complex evaluation of the child. Using this exhaustive information, the therapist is able to propose an intervention program that is personalised to the child's needs.

Furthermore, in the context of the recent changing of the work paradigm, when the therapy sessions are conducted in the format of teletherapy, the collaboration and the support offered by the therapist to the parents is essential for the success of the intervention program.
\end{abstract}

Keywords: language delays, telepractice, therapeutic teem, speech and language theraphy

\section{Introducere}

Tamis-LeMonda, Bornstein și Baumwell (2001) au evidențiat faptul că în primii ani de viață dezvoltarea comunicării și a limbajului este strâns legată de dezvoltarea globală a copilului și de aspectele senzorio-motorii, cognitive și socio-afective. În această perioadă se elaborează semnale de comunicare, adesea foarte subtile (emiterea de vocale, surâsuri, priviri, expresii faciale, mișcări ale corpului). Valoarea comunicativă a acestor semnale este strâns determinată de contextul specific în care ele sunt emise, astfel permit mamei și copilului să „converseze” legat de ceea ce există între ei „aici și acum”.

Implicarea efectivă a părinților în dezvoltarea limbajului propriilor copii se poate realiza oferindu-le metodele practice de a-și descoperii copiii și potențialitățile de comunicare (Bodea Hațegan, 2016).
Printre atribuțiile specialistului în terapia tulburărilor de limbaj și comunicare se află și necesitatea de a dezvolta sau încuraja reapariția unor anumite comportamente sau de a favoriza apariția de atitudini care să faciliteze dezvoltarea comunicării. Acesta va dirija ca eforturile de comunicare ale copilului să fie repetate și încurajate de părinți.

Bornstein \& Baumwell (2001, apud. Roberts, M și Kaiser, A., 2011) consideră că părinții dețin un rol extrem de important în dezvoltarea limbajului propriilor copii. Ei sunt recunoscuți ca fiind primii dascăli ai copiilor, având o influență puternică în primii ani de viață. În opinia autorilor, patru aspecte ale interacțiunii părinte copil sunt asociate $\mathrm{cu}$ dezvoltarea limbajului la copil:

-timpul ( cantitativ) de interacțiune părinte - copil;

- receptivitatea (părintelui) la intenția de comunicare a copilului; 
- cantitatea și calitatea stimulilor lingvistici prezenți în această interacțiune;

- utilizarea de strategii de susținere a învățării limbajului

Variații în îndeplinirea acestor aspecte sunt asociate de autorii citați cu diferențe în dezvoltarea limbajului atât la copiii cu o dezvoltare tipică, cât și la copiii cu tulburări de limbaj și comunicare.

\section{Experiențta ïnternațională}

În decursul ultimilor ani au apărut studii și programe dezvoltate de centre de terapii care au abordat rolul părinților în terapia tulburărilor de limbaj și comunicare dintro nouă perspectivă.

Centre precum „The Hanen Centre” din Toronto sau "The Michael Palin Centre for Stammering Children" din Londra, au dezvoltat programe de interacțiune în triada terapeut - copil - părinte, considerând părinții ca parte din echipă.

S-a pornit de la intenția de a transforma rolul de simplu observator al părintelui într-o persoană care să facă parte din procesul de terapie al copilului. Această schimbare are la bază câteva principii practice:

- copiii învață să comunice în timpul activităților zilnice și a interacțiunii cu cele mai importante persoane din copilăria lor - părinții;

-părinții au mai multe oportunități de interacțiune în situații diverse, cotidiene decât le-ar putea crea terapeuții;

-părinții sunt cei care își cunosc cel mai bine copilul și sunt primii săi educatori.

Programele de terapie propuse de aceste centre sunt organizate astfel încât să îi învețe pe părinți să gestioneze situațiile de comunicare $\mathrm{cu}$ proprii copii în mediul familial. Astfel, părinții învață să folosească strategii de construire a limbajului copiilor în rutina cotidiană. Ceea ce au observat coordonatorii acestor programe este faptul că, la modul practic, terapia:

-face parte din programul zilnic al copilului;

-îmbunătățește comunicarea și interacțiunea dintre copil și părinte, nu doar dintre terapeut și copil;

-implică jocuri și activități zilnice care au loc în contexte familiale (în timpul călătoriei cu mașina, a plimbărilor, la culcare, la băiță) și devin ușor de integrat spre deosebire de spațiul nefamiliar al cabinetului;

este distractivă și motivantă pentru copil;

În cadrul activităților și a discuțiilor comune, grupuri mici de părinți învață să profite de oportunitățile cotidiene $\mathrm{cu}$ scopul de a îmbunătăți abilitățile de comunicare ale copiilor.

Programele „The Hanen Centre” organizează sesiuni de trening în grupe combinate la care participă părinții și specialiștii în TLC dar și sesiuni individuale de trening la care participă părinții alături de copil și specialistul TLC. Acest fapt oferă o experiență de învățare personalizată și adaptată fiecărei familii participante.

Pentru părinții ai căror copii manifestă dificultăți de comunicare, programele The Hanen Centre sunt organizate astfel încât să le formeze instrumentele necesare în ai ajuta pe copii să își atingă sau să își lărgească potențialul de comunicare. Astfel, au fost dezvoltate programe pentru 
părinți care vizează: Întârzieri de limbaj, Tulburare din Spectrul Autist și Sindrom Asperger.

Programele The Hanen Centre pentru părinți presupun participarea efectivă a părinților în sesiuni de grup, apoi se individualizează ședințele prin implicarea familiei în activitățile desfășurate în cadrul Centrului urmate de utilizarea telepracticii în continuarea activităților de terapie în mediul familial.

Telepractica este termenul utilizat în mod frecvent pentru serviciile de evaluare și intervenție oferite de un specialist în terapia tulburărilor de limbaj și comunicare prin intermediul tehnologiei (telefon, email sau videoconferință) (Lowry, 2020). Aceste sesiuni de terapie pot fi oferite live (în timp real) sau pot fi înregistrate astfel încât să fie urmărite atunci când timpul este favorabil copilului.

Lowry (2020) trasează o serie de avantaje ale participării familiilor la terapie prin intermediul telepracticii, astfel:

- accesibilitatea - face referire la diminuarea unor inconveniente de ordinul transportului, a distanței de deplasare, fenomene meteo nefavorabile deplasării, etc.

-flexibilitate - programul întâlnirilor dintre familie și terapeut poate fi mult mai ușor de modificat în funcție de nevoile care intervin pe parcurs;

- eficiența - prin reducerea timpului de deplasare a terapeutului sau a familiei, de organizare a mediului cabinetului și de eliberare a acestuia pentru începerea unei noi sesiuni;

- perspectiva asupra familiei - prin intermediul videoconferinței terapeutul poate să urmărească cu mai multă precizie modul în care copilul desfășoară activități în mediul familial, ceea ce poate să ofere posibilitatea dirijării îndeaproape a programului desfășurat.

Programul de telepractică desfășurat de The Hanen Centre vizează sprijinirea părinților în acțiunea de îmbunătățire a abilităților comunicaționale ale copiilor. Acest obiectiv se realizează prin desfășurarea de întâlniri periodice cu familiile implicate (o dată pe săptămână timp de mai multe săptămâni) în cadrul cărora părinții primesc informații despre modul în care își pot ajuta copilul fiind îndrumați în acest demers și primind feedback permanent.

Specialiștii Centrului susțin faptul că învățarea limbajului de către copil se realizează în cea mai bună formă atunci când este lăsat să dirijeze conversația și se discută despre ceea ce-l interesează pe el mai mult. Programele propuse îi ajută pe părinți să își urmeze copilul în zona lui de interes astfel încât să îl mențină cât mai mult în interacțiune, oferindu-i stimuli și feedback-ul necesar să își construiască abilitățile de comunicare.

Datele înregistrate de organizatorii programelor de telepractică „The Hanen Centre" au arătat că, atât familiile cât și terapeuții participanți au raportat un nivel ridicat de satisfacție prin atingerea obiectivelor și reușita colaborării.

Programul de terapie coordonat de Centrul Michael Palin (Palin Centre) din Londra, se adresează copiilor cu vârste mai mari de 7 ani cu tulburări de ritm și fluență și organizează sesiuni de terapie prin 
modificarea modului de interacțiune dintre părinți și copil.

Palin Parent - Child Interaction (PCI) a fost dezvoltat în 1980 și se bazează pe încrederea acordată de terapeut și părinți profilului particular de pronunție al copilului, a punctelor tari și a vulnerabilităților prezente în vorbirea acestuia. Principiul de bază îl constituie faptul că părinții învață să interacționeze în permanență cu copiii în moduri care să le îmbunătățească abilitățile de comunicare, să sprijine fluența naturală și să crească timpii de interacțiune în mediul familial (Botterill \& Kelman, 2010).

Abordarea centrală este stabilirea unei relații de colaborare terapeutică în cadrul căreia sunt împărtășite cunoștințele și percepțiile terapeutului și ale părinților iar cei din urmă sunt încurajați să realizeze observații, să traseze propriile concluzii, să își fixeze scopurile în mod particular și să reflecteze asupra progreselor săptămânale. În cadrul acestei relații rolul terapeutul este de a facilita și a afirma, mai degrabă decât de a instrui, recomanda sau de a modela.

Părinții sunt încurajați să abordeze bâlbâiala în mod deschis, direct; sunt ajutați să își identifice fricile în legătură cu acest diagnostic. Prin definirea problemelor încă de la început, se poate reduce substanțial anxietatea familiei pe parcursul terapiei.

Botterill \& Kelman (2010) consideră ca prim scop al Palin PCI necesitatea de a forma o bază de cunoștințe, informații, abilități și încredere în managementul bâlbâielii ceea ce va sprijini terapia tulburărilor de ritm și fluență a copilului. Se are la bază ideea conform căreia părinții pot să influențeze abilitățile de comunicare ale copilului și încrederea în sine, iar aceasta, mai ales în cazul copiilor cu vârste mici, este un pivot pentru procesul de schimbare.

În timpul sesiunilor Palin PCI, părinții vizionează înregistrările făcute în timp ce se jucau cu copiii în cadrul clinicii. Conduși prin procesul de înțelegerea a nevoilor propriului copil, părinții primesc ghidaj în cadrul unui proces de identificare și de creștere a acelor interacțiuni și strategii de comunicare favorabile îmbunătățirii fluenței copilului.

\section{Directiii de cercetare}

Pornind de la datele analizate în literatura de specialitate, au fost trasate următoarele direcții de cercetare:

\section{Obiective}

Realizarea unui program de terapie a tulburărilor de limbaj și comunicare prin colaborarea dintre terapeut și părinți;

Proiectarea activităților de sprijin în cadrul cărora părinții primesc informații despre modul în care își pot ajuta copilul, fiind îndrumați în acest demers și primind feedback permanent;

Instrumentarea părinților cu strategii practice care să sprijine dezvoltarea limbajului funcțional al copilului în mod natural, în contextul cotidian al vieții de familie;

\section{Ipoteze}

Implicarea părinților în implementarea de strategii de intervenție specifice terapiei limbajului și a comunicării favorizează dezvoltarea abilităților verbale ale copilului; 
Organizarea ședințelor de terapie logopedică cu implicare parentală conduce la creșterea calității interacțiunii copil - părinți.

\section{Participantị}

La acest program de intervenție logopedică au participat 7 copii, 5 băieți și 2 fete, cu vârste cuprinse între 4-6 ani, diagnosticul logopedic stabilit ca urmare a evaluării complexe fiind de întârziere în dezvoltarea limbajului, dislalie polimorfă.

\section{Instrumente}

Inventarul de evaluare a limbajului expresiv/receptiv (pentru părinți) aplicat în etapele de pretestare și postestere

Diagnosticul tulburării de limbaj

- Proba de evaluare a nivelului de dezvoltare a limbajului(Stanica și Vrașmaș, 1997), Albumul logopedic, soft educaţional Logopedix

Diagnosticarea nivelului de cunoștințe și de performanță

- Baza materială din cadrul cabinetului: materiale intuitive, jocuri de asociere, etc.

Figura 1. Exemple de activități propuse în cadrul programului de terapie

\begin{tabular}{|c|c|c|c|}
\hline Tema & $\begin{array}{l}\text { Indicații pentru etapa } \\
\text { terapeutică }\end{array}$ & Recomandări & Observații \\
\hline $\begin{array}{l}\text { Construirea unor } \\
\text { interacțiuni pozitive } \\
\text { prin intermediul } \\
\text { jocului. }\end{array}$ & $\begin{array}{l}\text { Se iniţiază jocuri simple } \\
\text { cu ajutorul unor } \\
\text { figurine, mascote, care } \\
\text { să sprijine stabilirea } \\
\text { unei relaţii de } \\
\text { comunicare, a unei stări } \\
\text { de bine a copilului. }\end{array}$ & $\begin{array}{l}\text { Lăsaţi copilul să dirijeze } \\
\text { jocul. }\end{array}$ & $\begin{array}{l}\text { Se încurajează dorința } \\
\text { copilului de a se juca. Se } \\
\text { formează jocul copilului } \\
\text { (trecerea de la } \\
\text { manipularea efectivă a } \\
\text { jucăriei, la crearea unui } \\
\text { scenariu de joc). }\end{array}$ \\
\hline $\begin{array}{l}\text { Formarea şi dezvoltarea } \\
\text { abilităţilor de } \\
\text { discriminare, } \\
\text { identificare şi } \\
\text { interpretare a stimulilor } \\
\text { externi care apar în } \\
\text { mediul ambiant. }\end{array}$ & $\begin{array}{l}\text { Activităţi de percepţie şi } \\
\text { diferenţiere a } \\
\text { zgomotelor, sunetelor, } \\
\text { vocilor. } \\
\text { Exerciţii - joc pentru } \\
\text { dezvoltarea unor forme } \\
\text { ale atenţiei (auditivă, }\end{array}$ & $\begin{array}{l}\text { Atrageți atenția } \\
\text { copilului asupra } \\
\text { zgomotelor / sunetelor } \\
\text { din mediul ambiant, } \\
\text { îndreptați privirea spre } \\
\text { direcţia din care se aude }\end{array}$ & $\begin{array}{l}\text { Se încearcă } \\
\text { sensibilizarea atenţiei } \\
\text { copilului prin exerciţii } \\
\text { de identificare şi reacţie } \\
\text { la modificările care apar } \\
\text { în mediul ambiant. }\end{array}$ \\
\hline
\end{tabular}

Diagnosticul relației familie-copil

- Interviul cu părinţii

Au fost parcurse etape de :

-stimulare verbal-auditivă şi cognitivă;

- de întărire a abilităţilor de exprimare verbal-orală;

- dezvoltare a abilității de înțelegere a mesajului oral;

-părinţii au primit explicaţii ale exerciţiilor şi rolului lor în terapie precum şi răspunsurile care erau aşteptate din partea copilului;

- sumarizare a exerciţiilor parcurse şi a performanţelor înregistrate de copil, a obiectivelor urmărite, precum și a dificultăților întâmpinate;

-întocmire a listei de cuvinte din vocabularul de bază care să sprijine achiziția limbajului funcțional (diferit de la un copil la altul, în funcţie de stilul familial, de preferințele copilului, etc.)

- *se urmărește să folosească cuvinte şi propoziţii care îi sunt utile în viaţa de zi $\mathrm{cu}$ zi. 
vizuală, tactil-

kinestezică). zgomotul şi acordați

semnificant verbal.
Se încurajează formarea / menţinerea unui canal de comunicare deschis părinte-copil.

Figura 2. Exemple de sugestii pentru părinți

\begin{tabular}{ll}
\hline \hline Răspundeți prompt & $\begin{array}{l}\text { Este important ca să fiți atenți la intenția de comunicare a copilului și să răspundeți la } \\
\text { ceea ce face sau spune acesta }\end{array}$ \\
\hline Cuvinte noi & $\begin{array}{l}\text { Cuvintele sunt ușor de reținut atunci când sunt legate de context. Repetați cuvintele nou } \\
\text { apărute și asociați-le cu obiecte sau evenimente prezente }\end{array}$ \\
\hline Primele propoziții & $\begin{array}{l}\text { Orice încercare a copilului de a lega două sau mai multe cuvinte trebuie încurajată și } \\
\text { întărită. Repetați propoziția alcătuită de copil, chiar dacă nu este completă, oferind } \\
\text { varianta corectă într-un mod pozitiv }\end{array}$ \\
\hline $\begin{array}{l}\text { Povestea de „noapte } \\
\text { bună” }\end{array}$ & $\begin{array}{l}\text { Adaptați povestea citită, scurtați frazele complexe, ușurați limbajul astfel încât să îl } \\
\text { mențineți pe copil atent cât mai mult timp. Folosiți și alte cuvinte, mai ușor de perceput } \\
\text { de copil }\end{array}$ \\
\hline La cumpărături & $\begin{array}{l}\text { Folosiții acest prilej pentru a forma cuvinte noi. Întocmiți o mini listă de cumpărături pe } \\
\text { care să o urmăriți alături de copil. Acesta este un prilej bun de a-i explica faptul că poate } \\
\text { să cumpere doar ce este pe listă }\end{array}$ \\
\hline \hline
\end{tabular}

\section{Rezultate obținute}

Am ales ca metodă de cercetare, metoda studiului de caz pentru a urmări evoluția calitativă a aspectelor care țin de dezvoltarea individuală a participanților la programul de terapie. Din acest punct de vedere sumarizez câteva rezultate obținute în acest demers.

Analizând Diagrama 3, care ilustrează răspunsurile părinților la Inventarul de evaluare a limbajului expresiv/receptiv, în cele două etape de pretestare respectiv postestare, putem observa o îmbunătățire considerabilă a percepției părinților asupra evoluției limbajului expresiv și receptiv al copilului.

Astfel, un progres remarcabil se evidențiază în cotarea abilității copilului de a cere în mod explicit mâncare (itemul 1) care a fost evaluat ca manifestându-se foarte $\operatorname{rar}(2)$ în etapa de pretestare, spre deosebire de etapa de postestare, când apare în chestionar evaluat $\mathrm{cu} 5$ echivalentul pentru de cele mai multe ori.

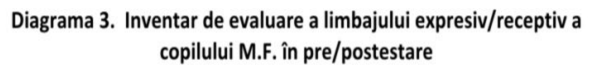
copilului M.F. în pre/postestare

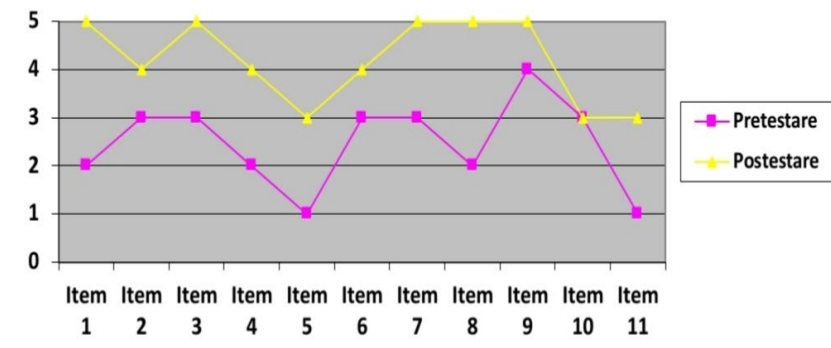

Un prim aspect urmărit a fost evoluția limbajului expresiv.Această arie a fost evaluată cu ajutorul itemului 3 care vizează utilizarea de cuvinte și expresii cu scopul de a denumi obiecte, persoane, acțiuni și a fost marcat de părinți ca fiind prezent într-o mai mare măsură decât în etapa inițială de pretestare, fiind cotat cu valoarea $5^{-}$corespunzătoare utilizării frecvente a limbajului verbal ca modalitate de interacțiune și comunicare. 
A doua dimensiune urmărită în cadrul Inventarului adresat părinților a fost cea a evoluției limbajului receptiv și a fost evaluat cu ajutorul itemului 8, care investighează percepția părinților în ceea ce privește abilitatea copilului de a înțelege și răspunde la întrebări simple. La acest item, părinții au bifat în pretestare indicele 2- corespunzător criteriului foarte rar, iar în etapa finală, în postestare indicele 5 - de cele mai multe ori.

Se remarcă din partea copilului o mai bună capacitate de exprimare verbală și un nivel mai bun al inteligibilității vorbirii sale resimțită de părinți. Însă, putem interpreta rezultatul obținut și prin faptul că implicarea directă a părinților în dezvoltarea abilităților de limbaj și comunicare ale propriului copil, are efecte benefice asupra stabilirii unui limbaj comun precum și o interacțiune mai bună prin creșterea timpului petrecut împreună.

La evaluarea realizată la patru luni de la demararea intervenției logopedice au fost sintetizate rezultate precum :

-s-a îmbunătăţit contactul vizual. Copilul direcţionează şi fixează privirea spre sarcina de lucra sau spre fața logopedului;

-sunt pronunţate toate vocalele cu apertura bucală specifică, iar nazalizarea este corectată în totalitate;

-sunt pronunţate consoanele ocluzive labiale şi dentale; se reuşeşte plasarea acestora în silabe directe şi inverse precum şi în cuvinte mono şi bisilabice în combinaţii intervocalice;

-s-a reuşit integrarea în mediul instituțional al grădiniței, crizele de ataşament fiind depăşite în mare măsură;

-sunt în curs de formare abilităţile de exprimare a propoziţilor cu rol de informare, cerere sau răspuns; de asemenea se antrenează formarea noţiunilor care exprimă spaţialitatea, temporalitatea, mărimea, distanța.

\section{Concluzii}

Participarea părinților în programul de terapie a tulburărilor de limbaj și comunicare a propriului copil prin colaborare terapeutică a contribuit la schimbarea percepției față de tulburarea de limbaj a copilului, a îmbunătățit interacțiunea cu acesta, devenind mai cooperanți și mai puțin critici.

Acest program de colaborare terapeutică dintre logoped, copil și părinți, a permis valorificarea observațiilor pe care părinții le realizează în mediul natural al copilului, în viața cotidiană, completând datele obținute în procesul de evaluare complexă a copilului și implicit propunerea unui program de intervenție personalizat nevoilor copilului.

Numărul redus de participanți implicați în prezenta cercetare, caracteristicile limbajului, vârsta acestora precum și buna implicarea a părinților în programul terapeutic, au condus la obținerea unor rezultate favorabile confirmării obiectivelor și a ipotezelor proiectate pentru acest studiu.

Tema abordată în această lucrare de cercetare poate fi valorificată în contextul actual al desfășurării în format telepractică a terapiei tulburării de limbaj și comunicare, având ca sugestie de continuare a cercetării extinderea eșantionului de participanți la studiu și 
realizarea unor ghiduri practice adresate părinților.

\section{Bibliografie}

Bodea Hațegan, C. (2016). Logopedia. Terapia tulburărilor de limbaj. Structuri Deschise, București: Editura Trei.

Botterill, W., Kelman, E. (2010). Palin Parent - Child Interaction. Chapter 5, in Treatment of Stuttering: Established and Emerging Interventions.

Lowry, L. (2020). Moving Hanen Parent Programs Online. Hanen Centre.

Roberts, M, Kaiser, A. (2011). The Effectiveness of Parent-Implemented Language Interventions: A MetaAnalysis, in American Journal of Speech-Language Pathology 20(3):18099

Tamis-LeMonda, $\quad$ C., $\quad$ Bornstein,M., Baumwell, L.(2001). Maternal Responsiveness and Children's Achievement of Language Milestones, Journal Child Development, May/June Volume 72, Number 3, Pages 748-767; http://www.hanen.org/Helpful-

Info/Articles/Moving-Hanen-Parent-

Programs-Online.aspx

http://downloads.lww.com/wolterskluwe r_vitalstream_com/samplecontent/9780781771047_Guitar/sample s/Chaptero5.pdf.

'.Prof. Logoped, Școala Profesională Specială.Câmpulung Moldovenesc, Suceava.

E-mail: $\underline{\text { luciabtz84@gmail.com }}$ 